\title{
Öğretmenlerin Sanal Sınıf Yönetimi Yeterlikleri
}

\author{
Ertuğ Canª, , Yüksel Gündüz
}

\section{Özet}

$\mathrm{Bu}$ araştırmanın amacı, öğretmenlerin sanal sınıf yönetimi yeterliklerini belirlemektir. Araştırma genel tarama modelinde tasarlanmıştır. Araştırmanın evrenini, 2020-2021 eğitim öğretim yılında Kırklareli ili merkez ve ilçelerinde görev yapan öğretmenler oluşturmaktadır. Araştırmanın örneklemi 329 öğretmenden oluşmaktadır. Araştırma verileri, Can ve Gündüz (2021) tarafından geliştirilen "Öğretmenlerin Sanal Sınıf Yönetimi Yeterliği Ölçeği" yardımıyla toplanmıştır. Ölçek 5'li likert tipinde ve 24 maddeden oluşmaktadır. Ölçeğin alt boyutları "öğrencilerle ilişkiler", "sanal sınıf içi etkinlikler" ve "sanal sinıf yönetimi"dir. Araştırma bulgularına göre, öğretmenlerin çoğunluğu sanal sınıf deneyimine sahip değildir. Öğretmenler, ölçeğin tüm alt boyutlarında sanal sınıf yönetimi konusunda kendilerini yeterli görmektedir. Kadın öğretmenlerin "sanal sınıf içi etkinlikleri" yönetme yeterlikleri erkek öğretmenlere göre istatistiksel açıdan anlamlı derecede daha yüksektir. Daha önce sanal sınıf deneyimi olan öğretmenlerin “Öğretmenlerin Sanal Sınıf Yönetimi Yeterliği Ölçeği", genel ve alt boyut toplam aritmetik ortalamaları, sanal sinıf deneyimi olmayanlardan anlamlı derecede daha yüksektir. Araştırma sonuçları, öğretmenlerin sanal sınıf yönetimi yeterliklerinin genel olarak yüksek düzeyde olduğunu ortaya koymaktadır.
Anahtar Kelimeler

Sanal Sinif

Sınıf Yönetimi

Sanal Sınıf Yönetimi

Sanal Sınıf Yönetimi Yeterliği

Makale Hakkında

Geliş Tarihi: 05.02.2021

Kabul Tarihi: 24.09.2021

Doi: 10.18026/cbayarsos.875435

\section{Teachers' Virtual Classroom Management Competences}

\begin{abstract}
The aim of this research is to determine teachers' virtual classroom management competences. The research is designed in general survey model. The population of the research consists of teachers working in the center and districts of Kirklareli province in the 2020-2021 academic year. The sample of the study consists of 329 teachers. The data of research was gathered with "the scale of teachers' virtual classroom management competences" developed by Can and Gündüz (2021). The scale is in 5-point Likert type and consists of 24 items. The sub-dimensions of the scale are "relations with students", "virtual classroom activities" and "virtual classroom management". According to the findings of research, most of teachers do not have virtual classroom experience. Teachers consider themselves competent in regard to virtual classroom management in all sub-dimensions of the scale. Female teachers' competences to manage "virtual classroom activities" is significantly higher than male teachers'. Relating to "the scale of teachers' virtual classroom management competences", general and sub-dimension total arithmetic averages of teachers having virtual classroom experience previously are significantly higher than those not having. The results of research put forward that teachers' virtual classroom management competences are generally at high level.
\end{abstract}

Keywords

Virtual Classroom

Classroom Management

Virtual Classroom Management

Virtual Classroom Management Competence

\section{About Article}

Received: 05.02.2021

Accepted: 24.09 .2021

Doi: 10.18026/cbayarsos.875435

a İletişim Yazarı: ertugcan@gmail.com

b Doç. Dr., Kırklareli Üniversitesi, Fen Edebiyat Fakültesi, Eğitim Bilimleri Bölümü, ORCID: 0000-0002-0885-9042.

c Doç. Dr., Ondokuz Mayıs Üniversitesi, Eğitim Fakültesi, Eğitim Bilimleri Bölümü, ORCID: 0000-0002-4710-8444. 


\section{Giriş}

Aralık 2019'da başlayan ve bir yılı aşkın bir süredir küresel düzeyde etkili olan Kovid-19 pandemisi yaşamın tüm alanlarını doğrudan olumsuz yönde etkilemiştir. Bunun sonucu olarak küresel düzeyde yüz yüze eğitime ara verilmiş ve uzaktan eğitime geçilmiştir. Eğitim öğretim uygulamaları uzaktan eğitim olanakları ile sanal ortamda gerçekleştirilmeye başlamıştır. Sanal ortamda gerçekleştirilen eğitimin süresinin pandemi sürecine göre şekilleneceği ortadadır. Bu süreçte ülkeler, eğitim öğretimin kesintiye uğramadan devam etmesi için farklı tedbirlere başvurmakta ve sanal ortamda eğitimi sürdürmeye çalışmaktadırlar. Kovid-19 pandemisine bağlı olarak küresel düzeyde ortaya çıkan bu kriz durumu ile birlikte sanal sinıflarda yürütülen öğretimin etkililiği ve eğitimcilerin yeterliği konusu gündeme gelmektedir. Sanal ortamda yürütülen öğretim uygulamalarının niteliğini etkileyen sanal sınıflara özgü pek çok faktör bulunmakla birlikte, öğretmenlerin sanal sınıf yönetimi konusundaki yeterliğinin önemli bir faktör olduğu söylenebilir.

\section{Sanal sinıflar ve özellikleri}

Alan yazın taramasında birbirine benzer değişik sanal sınıf tanımlamalarının yapıldığ görülmektedir. Bu tanımlar incelendiğinde; Öğrencilerin aynı zamanda farklı mekânlarda bir öğretmen rehberliğinde, öğretmen ve öğrenciler arasında değişik yöntemlerle çift yönlü iletişimin gerçekleştiği çevrimiçi öğrenme ortamı (Clark, \& Kwinn, 2007; Kaya, 2011, s.87), öğretenlerin ve öğrenenlerin aynı ortamda bulunma zorunluluğu olmadan öğrenme ve öğretme etkinliklerinin sanal sınıf yazılımları aracılığıyla eş zamanlı (senkron) veya eş zamansız (asenkron) olarak etkileşime dayalı gerçekleştirildiği sanal ortamlar (Can, 2020a, s.252-253) şeklinde tanımlandığ1 görülmektedir.

Martin, \& Parker'in (2014) belirttiği gibi, sanal sınıflar genellikle öğrenenlerde etkileşimi artırarak topluluk bilinci geliştirme ve farklı yerlerde bulunan öğrenenlere ulaşmak gibi amaçlarla tercih edilmektedir. Bu yüzden, Lugrin, Latoschik, Hobel, Roth, Seufert, \& Grafe'e (2016) göre, sanal ortamlar tasarlanırken düşük maliyetli, kullanışlı, uyarlanabilir, geribildirime olanak sağlayan, gerçekçi, güvenli ve rahat olmalıdır. Ayrıca, Can'a (2020a, s.262) göre, sanal sınıflarda eş zamanlı (senkron) dersler zaman bakımından bağımlı, mekân bakımından bağımsız, eş zamansız (asenkron) dersler ise zaman ve mekân bakımından bağımsız ortamlarda gerçekleştirilmektedir.

Sanal sınıf uygulamaları, etkili ve hızlı geribildirim olanağı ile ailelerin de öğrenenlerin eğitim yaşantısına hızlı ve etkin katılımını sağlaması (Can, 2020a), sanal derslere erişim özgürlüğü sunması, eğitimin maliyetini düşürmesi (Liu, Lomovtseva, \& Korobeynikova, 2020), ulaşım maliyetini azaltması (Willman, Zebedin, \& Miksche, 2020), kendini ifade etmekte zorlanan içe dönük öğrencilerin derslere katılımına olanak sağlaması (Mills, 1996), esneklik, iletişim ve işbirliği (Gedera, 2014; Rufai, Alebiosu, \& Adeakin, 2015), mantıksal akıl yürütme ve soyut teorik bilgileri geliştirme (Liu, 2015), maliyetli ve riskli deneylerin yapılmasına olanak sağlaması (Fan, \& Zhi, 2020; Can, 2020a) bakımından önemli avantajlar sağlamaktadır. Ancak, sanal sınıf uygulamalarının bu avantajlarına rağmen teknolojik altyapı başta olmak üzere uygulamada değişik sorunlarla da karşılaşılabilmektedir.

Sanal sinıf uygulamalarında altyapı ve teknik sorunlar (Akkuş ve Acar, 2017; Can, 2020a; Dikmenli ve Ünald1-Eser, 2013; Erten, 2019; Gedera, 2014; Kırmac1 ve Acar, 2018; Winther, 1999), içerik ve materyal yetersizliği (Akkuş ve Acar, 2017), etkileşim ve iletişim sorunları (Dumont, \& Raggo, 2018; Kalelioğlu, Atan ve Çetin, 2016), güvenlik sorunu (Winther, 1999), 
derslere erişimde sorunlar, sosyal ve fiziksel uzaklık ile öğrenci başarısını değerlendirmede karşılaşılabilecek sorunlar (Can, 2020a), sanal derslerin yüz yüze dersler kadar etkili olmaması (Bettinger, Fox, Loeb, \& Taylor, 2017); disiplin ve ciddiyet eksikliği (Erten, 2019) gibi olumsuzluklarla karşılaşılabilmektedir. Ayrıca, sanal sınıf uygulamalarında karşılaşılabilecek diğer sorunlar olarak, evde ebevyn desteğinin ve uygun öğrenme ortamının olmaması (Ferri, Grifoni \& Guzzo, 2020), özel eğitim öğrencilerinin rehberlik ihtiyacı (Pokhrel \& Chhetri, 2021), öğrencilerin zaman yönetimi ve motivasyona bağlı sorunlar yaşamaları (Fidalgo, Thormann, Kulyk \& Lencastre, 2020), öğretmenlerin alan bilgisi, bilgisayar kullanma becerisi ve çevrim içi öğretim yöntem ve teknikler konusunda yeterli olmamaları ve sanal sınıf deneyimi eksiklikleri (Mishra, Gupta \& Shreee, 2020), siralanmaktadır. Sanal sınıf uygulamalarında karşılaşılan bu tür olumsuzlukların doğal olarak sanal sınıf uygulamalarının etkililiği ile öğretmenlerin sanal sınıf yeterliği üzerinde büyük bir etkisi olabileceği söylenebilir. Ayrıca, sanal ortamda yürütülen eğitim etkinliklerinde, sanal sınıfların büyüklügünün öğretimin kalitesini ve öğrenciler arasındaki etkileşimi etkilediği, 23-25 kişilik sınıflarda öğrenci memnuniyetinin daha yüksek olduğu (Kingma, \& Keefe, 2006) belirtilmektedir.

Martin, Parker, \& Ndoye (2011), sanal sinıflarda öğrencilerin birbirleriyle ve öğretmenlerle etkileşimlerinin önemli olduğunu, böylece öğrencilerin kendlerini sosyal bir varlık olarak hissettiklerini, ayrıca arkadaşlarından ve öğretmenlerinden geribildirim alarak motive olduklarını belirtmektedir. Bu yüzden, Karaman, Aydemir, Küçük, \& Yıldırım'a (2013) göre, öğrencilerin sanal sınıf oturumlarına etkin katılımını ve motivasyonunu sağlayabilmek için kullanılan yöntem, teknik ve materyallerin öğrencilerin ilgisini çekmesi ve iyi bir planlama yapılmasına ihtiyaç bulunmaktadır.

Sanal sınıflarda yürütülen öğrenme-öğretme etkinliklerinin başarısı ve sınıf yönetiminin etkililiğinde sanal sınıf öğeleri ile sanal sınıf yönetimi boyutlarının esas alınması, öğretmenlerin bu alanlarda yeterliklerinin sağlanması olumlu katkılar sağlayacaktır. Bigatel, Ragan, Kennan, May, \& Redmond (2012), sanal ortamdaki derslerin başarılı olabilmesi için sosyal olarak bir öğrenme ortamının olması, öğrencilerin bir öğrenme topluluğu oluşturması ve öğrencilerin aktif olarak öğrenme aktivitelerine katılması şeklinde üç koşulun önemini vurgulamaktadır. Ayrıca, sanal ortamda öğrenci merkezli bir öğretim için etkileşim, iletişim ve öğrencilerin aktif katılımı önemli görülmektedir.

Sanal ortamda kullanılan öğrenme materyallerinin standardizasyonu ve değerlendirme sistemi oluşturulması, öğrencinin değerlendirilmesi ve yeterlilik sisteminin oluşturulması (Li, Hsu, Chang., \& Heh, 1999), sanal ortamda eğitim yürütenlerin başarısını belirlemeye yönelik birtakım standartların belirlenmesi (Bigatel, Ragan, Kennan, May, \& Redmond, 2012), teknolojik altyapının sağlanması ve etkili kullanımı (Berge, 1995) önerilmektedir. Ayrıca, sanal eğitim ortamlarında öğretim uygulamalarının etkililiğinde öğrenmeyi öğretme ve izleme stratejileri ile öğrencilerin sanal öğrenme ortamlarında öğrenmeye yönelik motivasyonlarının önemli bir faktör olduğu (Beluce, \& Oliveira, 2016) belirtilmektedir. Karaman, Aydemir, Küçük, \& Yıldırım'ın (2013) araştırma sonucuna göre, sanal sınıf oturumlarının tasarımı, sanal sınıfın hem etkinliklerinin hem de materyallerinin öğrenmeyi ve öğrencinin öğrenme ortamına dahil olma algısını desteklemesi gerektiği, öğrencilerin ilgisini çeken ve aktif katılımını sağlayan yöntemler kullanılması, her oturum öncesinde, sırasında ve sonrasında öğrencilere ve eğitmenlere sürekli teknik destek sağlanması gerekmektedir. 


\section{Sanal sınıf yönetimi}

Etkili sınıf yönetimi, yüksek beklentileri belirleme ve iletme, olumlu ilişkileri sürekli olarak besleme ve yüksek düzeyde öğrenci desteği sağlamaya dayanır (APA, 2020). Sanal sınıf yönetimi, sanal ortamdaki öğrenmenin etkililiği için uygun öğrenme ortamının sağlanması ve sürdürülmesi ile ilgili çabalar (Can, 2020a, s.262), çevrimiçi ortamda öğrenenler ile öğrenenlerin buluştuğu bir çevrimiçi öğrenme sistemi (Ceylan, 2020), farklı ortamlarda bulunan öğrencilerin öğretmen rehberliğinde eş zamanlı olarak çevrim içi ortamda bir araya gelerek bilginin teknoloji tabanlı paylaşıldığı, öğrenmenin gerçekleştirilmesine yönelik sanal sınıf düzeninin ve kuralların sağlanması ve sürdürülmesi (Kaya, 2011) şeklinde tanımlanmaktadır. Bu özellikler, sanal sınıf uygulamalarını gerçekleştiren öğretmenlerin derslerin planlanması, tasarımı, sunumu, teknolojik araçların kullanımı, öğrenci başarısının ölçülmesi ve değerlendirilmesi ile davranışların yönetimi gibi pek çok alanda yeterli olmalarını gerektirmektedir. Can'ın (2020a, s.255) belirttiği gibi, sanal sınıflarda öğreten ile öğrenenin sosyal ve fiziksel uzaklığına bağlı olarak öğrenme farklı ortamlarda gerçekleşmektedir. Bu durum, geleneksel sınıflarla karşılaştırıldığında, sanal sınıfların yönetimini farklılaştırmaktadır. Ancak, geleneksel sınıflar için geçerli olan öğreten, öğrenen, içerik, yöntem-teknik, araç-gereç ve başarı değerlendirme gibi faktörlerin sanal sınıf yönetiminde de önemli olduğu belirtilmektedir.

Sanal sınıf yönetimi öğeleri, sanal ortam, öğrenciler, kaynaklar, zaman engellerinin kaldırılması, katılım (Ceylan, 2020), öğreten, öğrenen, yöntem, teknik, organizasyon, içerik, teknoloji (Can, 2020a), öğretim stratejileri, organizasyon, öğrenme materyalleri, teknoloji (Albrecht, 2003) olarak sanal sinıfların yönetimini doğrudan etkileyen öğeler olarak sıralanabilir. Bununla birlikte, öğretmenlerin sanal sınıf yönetimi yeterliklerini etkileyen en önemli değişkenler arasında sanal sınıf yönetimi boyutları yer almaktadır. Geleneksel sınıflar için geçerli olan fiziksel düzen, plan-program etkinlikleri, sınıf içi ilişkiler, zaman yönetimi, davranış düzenlemeleri, olumlu sınıf iklimi yaratma, motivasyon (Aydın, 2017; Başar, 2011; Erden, 2005) şeklindeki sınıf yönetimi boyutları, sanal sınıfların yönetiminde de büyük öneme sahiptir. Ancak, sanal sınıflarda öğretme-öğrenme etkinliklerinin sanal ortamda gerçekleşmesi nedeniyle içerik ve özellik bakımından farklılıklar gösterebilir. Örneğin, Ceylan (2020), sanal sınıf yönetimi boyutlarını fiziksel düzenlemeler, plan-program etkinlikleri, ilişki düzenlemeleri, davranış düzenlemeleri ve zaman yönetimi şeklinde sınıflandırmaktadır. Can (2020a, s.268) ise sanal sınıf yönetimi boyutlarını, öğretim ortamı, öğretimin yönetimi, davranışların yönetimi, etkileşim, motivasyon, teknolojinin yönetimi, özel gereksinimli öğrencilerin yönetimi ve zaman yönetimi olmak üzere 8 boyutta ele almaktadır. Sanal sınıf yönetimi boyutları esas alındığında öğretmenlerin bu boyutların her birinde, bilgi, beceri, tutum ve davranış bakımından gerekli yeterliklere sahip olmaları beklenmektedir. $\mathrm{Bu}$ bağlamda, öğretmenlerin sanal sınıf yönetimi yeterliklerinin araştırılması önemli görülmektedir.

$\mathrm{Bu}$ araştırmanın amacı, öğretmenlerin sanal sınıf yönetimi yeterliklerini belirlemektir. $\mathrm{Bu}$ amaç altında araştırmanın problem cümlesi, "öğretmenlerin sanal sınıf yönetimi yeterlikleri ne düzeydedir?" şeklinde ifade edilerek aşağıdaki sorulara yanıt aranmıştır:

1. Öğretmenlerin sanal sınıf yönetimi yeterlikleri ne düzeydedir? 
2. Öğretmenlerin sanal sınıf yönetimi yeterlikleri ile cinsiyet, branş, öğrenim düzeyi, meslekî kıdem, sanal sınıf deneyimi ve görev yapılan kurum değişkeni arasında anlamlı bir farklılık var midir?

\section{Araştırmanın önemi}

Son zamanlarda küresel düzeyde etkili olan Kovid-19 Pandemisi ile birlikte yaygınlaşan sanal sınıf uygulamaları, sanal sınıfların yönetimini ve etkililiğini gündeme getirmektedir. Sanal sınıflarda gerçekleştirilen öğretim uygulamalarının etkililiği ve başarısında sanal sınıfların yönetimi büyük rol oynamaktadır. Sanal sınıfların etkili yönetimi de öğretmenlerin bu alandaki yeterlikleri ile doğrudan ilişkilidir. Ancak, ulusal ve uluslararas düzeyde basılı ve elektronik ortamda gerçekleştirilen alan yazın taramasında sanal sınıflarda öğretmenlerin sınıf yönetimi yeterliği ile ilgili yeterli sayıda araştırmanın yer almadığı, ya da çok sınırlı olduğu görülmektedir. Var olan araştırmaların da genellikle konunun belirli yönlerini kuramsal yönden ele aldıkları dikkat çekmektedir. Bu araştırma, öğretmenlerin sanal sınıf yönetimi yeterliklerini belirlemeye yönelik ilk araştırmalardan biri olarak, sanal sınıf uygulamalarını gerçekleştiren öğretmenlerin görüşlerine göre bu alandaki yeterliklerinin belirlenmesi bakımından büyük önem taşımaktadır. Buradan elde edilecek bulgular ile öğretmenlerin sanal sınıf yönetimi yeterliklerinin gelişimine ve sanal sınıf yönetimine önemli katkılar sunulabileceği değerlendirilmektedir.

\section{Yöntem}

$\mathrm{Bu}$ bölümde araştırmanın modeli, evren ve örneklem, veri toplama araçları, verilerin toplanması ve verilerin analiz ile ilgili bilgiler yer almaktadır.

\section{Araştırma Modeli}

Öğretmenlerin sanal sınıf yönetimi yeterliğine ilişkin yapılan bu araştırmada, araştırmanın amacına uygunluğu yönünden genel tarama modeli kullanılmıştır. Karasar'a (2019) göre, tarama modeli, çok sayıda elemandan oluşan bir evrende, evrenle ilgili genel bir yargıya varmak amacıyla evrenin tümü ya da ondan alınacak bir grup, örnek ya da örneklem üzerinde yapılan tarama düzenlemeleridir.

\section{Evren ve Örneklem}

$\mathrm{Bu}$ araştırmanın evrenini 2020-2021 eğitim öğretim yılında Kırklareli ili Merkez (1.119), Babaeski (371) ve Vize (267) ilçelerinde görev yapmakta olan 1.757 öğretmen oluşturmaktadır. Örneklemi ise evrenden basit tesadüfi örnekleme yöntemi ile seçilen 329 öğretmen oluşturmaktadır. Farklı büyüklükteki evren için kuramsal olarak örneklem büyüklüğü \%5 hata düzeyi ve \%95 güven düzeyine göre, 5000'lik bir evrenden 356 örneklem yeterli bulunmaktadır (Anderson, 1990; aktaran Balc1, 2004).

Araştırmaya katılım sağlayan öğretmenlerin kişisel özelliklerine ilişkin veriler Tablo 1.'de sunulmuştur. 
Tablo 1. Öğretmenlerin Kişisel Özelliklerine İlişkin Frekans Dağılımları

\begin{tabular}{|c|c|c|c|}
\hline Kişisel Özellikler & Özellik Kategorileri & Frekans(f) & Yüzde $(\%)$ \\
\hline \multirow{3}{*}{ Cinsiyet } & Kadın & 242 & 73,60 \\
\hline & Erkek & 87 & 26,40 \\
\hline & Toplam & 329 & 100 \\
\hline \multirow{4}{*}{ Branş1 } & Okul Öncesi Öğretmeni & 49 & 14.9 \\
\hline & Sınıf Öğretmeni & 135 & 41.0 \\
\hline & Branş Öğretmeni & 145 & 44.1 \\
\hline & Toplam & 329 & 100 \\
\hline \multirow{3}{*}{ Öğrenim Düzeyi } & Lisans & 279 & 84.8 \\
\hline & Lisansüstü & 50 & 15.2 \\
\hline & Toplam & 329 & 100 \\
\hline \multirow{5}{*}{ Meslekî Kıdem } & $1-5$ yil & 47 & 14,3 \\
\hline & 6-10 yıl & 85 & 25,8 \\
\hline & $11-15$ yıl & 62 & 18,8 \\
\hline & $16-20$ yil & 47 & 14,3 \\
\hline & $21-25$ yil & 60 & 18,2 \\
\hline \multirow{5}{*}{ Sanal Sinıf Deneyimi } & 26 yıl ve üstü & 28 & 8,5 \\
\hline & Toplam & 329 & 100 \\
\hline & Var & 115 & 35 \\
\hline & Yok & 214 & 65 \\
\hline & Toplam & 329 & 100 \\
\hline \multirow{5}{*}{ Görev Yaptığ1 Kurum } & Okul Öncesi & 42 & 12,8 \\
\hline & İlkokul & 142 & 43,2 \\
\hline & Ortaokul & 54 & 16,4 \\
\hline & Lise & 91 & 27,7 \\
\hline & Toplam & 329 & 100 \\
\hline
\end{tabular}

Tablo 1.'e göre, örneklem grubunun \% 73.6'i kadın, \% 26.4'ü erkektir. Araştırmaya katılan öğretmenlerin çoğunluğu lisans mezunudur (\% 84,8). Lisansüstü öğrenim gören öğretmenler bu çalışmada \% 15.2 ile temsil edilmişlerdir. Öğretmenlerin branş değişkenine göre dağılımları incelendiğinde; \% 14,9'u okul öncesi, \% 41'i sınıf öğretmeni ve \% 44.1 'i branş öğretmeni oldukları görülmektedir. Öğretmenlerin \% 35'inin daha önceden sanal sınıf yönetimi deneyimi bulunmaktadır. Sanal sınıf yönetimi deneyimi bulunmayan öğretmenler bu çalışmada \%65 ile temsil edilmişlerdir. Öğretmenlerin meslekî kıdem değişkenine bakıldığında; ilk sırayı 6-10 yıl arasında çalışanlar almıştır (\% 25.8), bunu \% 18,8 ile çalışma yılı 6-10 yıl arasında olanlar ikinci sırada izlemiştir. Son sırada \% 8.5 ile çalışma süresi 26 yıl ve üstü olanlar bulunmaktadır. Araştırmaya katılan öğretmenlerin \% 12.8'i okul öncesi kurumlarda, \% 43.2'si ilkokullarda, \% 16,4'ü ortaokullarda ve \% 27,7'si ise liselerde görev yapmaktadir.

\section{Veri Toplama Araçları}

$\mathrm{Bu}$ araştırmada verileri toplamak amacıyla Can ve Gündüz (2021) tarafından geliştirilen "Öğretmenlerin Sanal Sınıf Yönetimi Yeterliği Ölçeği” kullanılmıştır. Ölçek iki bölümden oluşmaktadır. Ölçeğin birinci bölümünde katılımcıların cinsiyeti, eğitim durumu, branşı, daha önceden sanal sınıf yönetimi deneyimi olup olmadığı, meslekî kıdemi, görev yapılan eğitim kurumu şeklindeki demografik özelliklerini belirlemeye yönelik altı soru bulunmaktadır. 
Ölçeğin ikinci bölümünde ise 5’li Likert tipi 24 soru yer almaktadır. Ölçek üç alt boyuttan oluşmaktadır. Birinci alt boyut olan "öğrencilerle ilişkiler" 11 sorudan oluşmaktadır (14-15-1617-18-20-21-22-23-24-25.maddeler). Bu maddelerin faktör yükleri .78 ile .54 arasındadır. İkinci alt boyut olan "sanal sınıf içi etkinlikler", 8 maddeden (6-7-8-9-10-11-12-13 maddeler) oluşmakta ve faktör yükleri maksimum .75 ile minimum .57 arasındadır. Üçüncü alt boyut olan "sanal sınıf yönetimi" ise 5 maddeden (1-2-4-5-19. maddeler) oluşmaktadır. Faktör yükleri maksimum .79 ve minimum .49 arasında değişmektedir.

Ölçeğe ilişkin uyum indeksleri incelendiğinde; AGFI değerinin 0,80 ve GFI değerinin 0,84 olduğu görülmektedir. Byrne (1998)'ye göre AGFI ve GFI değerinin 0,80'in üzerinde olmasi kabul edilebilir uyumu göstermektedir. CFI $(0,97)$, NFI $(0,95)$ ve NNFI $(0,96)$ değerlerinin ise 0,95'in üzerinde olması mükemmel bir uyumun göstergesidir. Çokluk, Şekercioğlu ve Büyüköztürk'e (2010) göre GFI, AGFI, CFI, NFI, NNFI, IFI ve RFI uyum indeksleri için iyi uyum değeri 0.90 ; mükemmel uyum değeri ise 0.95 ve üstü değerler olarak kabul edilmektedir. RMSEA $(0,080)$ ve SRMR $(0,057)$ değerlerinin de 0,08 'in altında olması iyi bir uyumun olduğunu göstermektedir.

Ölçeğin yapı geçerliği için alt boyutların kendi aralarındaki ve toplam puanlarla korelasyonu incelendiğinde, üç boyutun sırasıyla toplam puanlar arasındaki korelasyonlar; .874, .727, ve .819 olarak istatistiksel açıdan anlamlıdır. Alt boyutlar arasındaki korelasyonlar maksimum .58 ve minimum .34 arasında değişmektedir. Bu sonuçlar ölçeğin yapı geçerliğine sahip olduğunu göstermektedir.

Ölçeğin güvenirlik analizi çalışmalarında, her bir alt boyut ve test toplam için Cronbach Alfa $(\alpha)$ katsayıları yardımıyla iç tutarlılık katsayıları bulunmuştur. Test toplamın güvenirlik katsayısı .909; birinci alt ölçeğin .910; ikinci alt ölçeğin .832 ve üçüncü alt ölçeğin ise .765 olmuştur. Hem test toplamda ve hem de alt boyutlarda maddelerin güvenirlik katsayıları (item-total korelasyonları) hesaplanmış ve hepsinin istatistiksel açıdan çok yüksek düzeyde anlamlı olması bütün maddelerin güvenilir olduğunu göstermektedir.

\section{Verilerin Toplanması ve Analizi}

Araştırma verilerinin toplanmasından önce Kırklareli Üniversitesi Bilimsel Araştırmalar ve Yayın Etiği Kurulu'ndan 15/10/2020 tarih ve 35523585-199-E.15316 sayılı Etik Kurulu Onayı alınmıştır. Ayrıca, araştırma gönüllü katılımcılarla bilgilendirme sonrasında yürütülmüştür.

İlk aşamada yanıtlanmış tüm ölçekler, araştırmacılar tarafından tek tek incelenmiş ve sağlıklı doldurulmamış ölçekler iptal edilmiştir. Daha sonra ölçeklerin sağlıklı bir şekilde doldurulduğu anlaşıldıktan sonra, toplanan tüm ölçme araçlarına birer kod (ID) numarası verilmiştir. Sırayla SPSS programında veri girişleri yapılmıştır. Tüm veri girişi yapıldıktan sonra verilerin sağlıklı bir şekilde giriş yapılıp yapılmadığı araştırılmıştır. Veri girişlerinde herhangi bir sorun olmadığı anlaşıldıktan sonra veri analizi işlemlerine geçilmiştir.

Öğretmenlerin Sınıf Yönetimi Yeterliği Ölçeğinin alt boyutları olduğu için toplam ve alt boyutların aritmetik ortalamaları belirlenmiştir. Burada $4 / 5=0.8$ sonucuna ulaşılmış olup, buna göre 4.22-5: Kesinlikle Katılıyorum; 3.43-4.21 Katılıyorum; 2.62-3.42 Kararsızım 1.81-2.61 Katılmıyorum; 1-1.80 Kesinlikle Katılmıyorum değerlendirme kriterlerine ulaşılmıştır. Betimsel istatistikî değerler incelendiğinde Öğretmen Sanal Sınıf Yönetimi Yeterliği Ölçeğinden elde edilen verilere ilişkin merkezî eğilim ölçüleri içinde aritmetik ortalama ve medyan değerlerinin birbirine çok yakın olduğu ve çarpıklık basıklık değerlerinin $+1,-1$ aralığında olduğu görülmektedir. Merkezi eğilim ölçülerinin birbirine yakın olması ve 
çarpıklık basıklık değerlerinin $+1,-1$ aralığında olması dağılımın normalliği olarak yorumlanabilir (Büyüköztürk, 2011; Can, 2013).

Araştırmanın veri analiz bölümünde ilk etapta demograik özellikleri ölçmeye yönelik sorulara verilen yanıtların frekans ve yüzdelik dağılımları bulunmuştur. İkinci aşamada araştırmada kullanılan ölçeklerin toplam, alt boyut ve maddelerinin aritmetik ortalama ve standart sapmaları belirlenmiştir. Ölçek toplam aritmetik ortalamalarına göre öğretmenlerin sanal sınıf yönetimi yeterlikleri puanları yorumlanmıştır. Üçüncü aşamada ölçekte yer alan bağımsız kategorik değişkenlere göre ölçek alt boyut ortalamaları arasındaki farklılıkların sınanması için ilişkisiz grup " $\mathrm{t}$ ” testi (kategori sayısı iki olduğunda) ve Tek yönlü varyans analizi (ANOVA) (kategori sayısı ikiden daha fazla olduğu durumlarda) işlemi yapılmıştır. ANOVA'da istatistiksel açıdan farklılık bulunduğu durumlarda bu kümülatif farklılığın hangi ikili gruplar arasından kaynaklandığını belirlemek için post-hoc tekniklerden Scheffe veya tamhane çoklu karşılaştırma testi gerçekleştirilmiştir. Araştırmada bütün sonuçlar çift yönlü olarak sınanmış ve anlamlılık düzeyi en az 0.05 olarak kabul edilmiştir. Anlamlılık düzeyleri ilgili tablolarda kesin değerleriyle yer almıştır. Araştırmanın tüm istatistik analizleri SPSS 14,0 programı ile gerçekleştirilmiştir.

\section{Bulgular}

Öğretmenlerin sanal sınıf yönetimi yeterlik ölçeği toplamlarının tanımlayıcı istatistik değerleri Tablo 2'de sunulmuştur.

Tablo 2. Öğretmenlerin Sanal Sınıf Yönetimi Yeterlik Ölçeği Toplamlarının Tanımlayıcı İstatistik Değerleri

\begin{tabular}{lccc}
\hline Alt Boyutlar & N & $\bar{X}$ & SS \\
\hline Öğrencilerle ilişkiler & 329 & 3,5739 &, 68316 \\
Sanal sinıf içi etkinlikler & 329 & 4,0824 &, 55602 \\
Sanal sinıf yönetimi & 329 & 3,6036 &, 68946 \\
Toplam & 329 & 3,7533 &, 52200 \\
\hline
\end{tabular}

Tablo 2 incelendiğinde, ölçek toplam puanlarının aritmetik ortalaması $\overline{\mathrm{x}}=3.75^{\prime}$ tir. Bu sonuç, ölçeğin değerlendirme sisteminde "katılıyorum" sınırları içindedir. Tümüyle katılıyorum diyenler " 5 " puan, "hiç katılmıyorum" diyenler "1" puan almaktadırlar. Ölçekten alınan yüksek puan sanal sınıf yönetim yeterliğinin yüksekliğini, düşük puanlar ise yeterlik düzeyinin düşüklüğünü göstermektedir. Ölçek toplamdan alınan sonucun $\bar{x}=3,75$ olması nedeniyle öğretmenlerin sanal sınıf yönetimindeki yeterliklerinin yüksek düzeyde olduğu söylenebilir. Alt boyutların sonuçlarına göre en yüksek değer $\bar{x}=4.08$ ile sanal sınıf içi etkinliklerden alınmıştır. Bu sonuç "katılıyorum" sınırları içindedir. "Sanal sınıf yönetimi" alt ölçeği aritmetik ortalaması $\bar{x}=3,60$ ve "öğrencilerle ilişkiler" alt boyut ortalaması $\bar{x}=3,57^{\prime}$ dir. Tüm bu sonuçlar "katılıyorum" sınırları içinde olup, öğretmenlerin sanal sınıf yönetimi konusunda kendilerine yeterli düzeyde güvendiklerini ve sanal sınıf yönetimi konusunda kendilerini yeterli gördüklerini göstermektedir.

Öğretmenlerin cinsiyet değişkenine göre “Öğretmenlerin Sanal Sınıf Yönetimi Yeterliği Ölçeği" için yapılan ilişkisiz grup " $t$ ” testi sonuçları Tablo 3 'te sunulmuştur. 
Tablo 3. Cinsiyet Değişkenine Göre Öğretmenlerin Sanal Sınıf Yönetimi Yeterliği Ölçeği Genel ve Alt Boyut Toplam Puan Ortalamaları Arasındaki Farklar

\begin{tabular}{llrccccc}
\hline Alt Boyutlar & Cinsiyet & $\mathbf{N}$ & $\bar{X}$ & SS & t & sd & P \\
\hline Öğrencilerle ilişkiler & Kadın & 242 & 3,5980 &, 66956 & 1,069 & 327 & 286 \\
& Erkek & 87 & 3,5068 &, 71939 & & & \\
Sanal sınıf içi etkinlik & Kadın & 242 & 4,1307 &, 50814 & 2,648 & 327 &, $008^{* *}$ \\
& Erkek & 87 & 3,9483 &, 65635 & & & \\
Sanal sınıf yönetimi & Kadın & 242 & 3,5876 &, 68585 &,- 703 & 327 &, 482 \\
& Erkek & 87 & 3,6483 &, 70147 & & & \\
Toplam & Kadın & 242 & 3,7721 &, 49893 & 1,088 & 327 &, 277 \\
& Erkek & 87 & 3,7011 &, 58130 & & & \\
\hline
\end{tabular}

${ }^{*} \mathrm{p}<.05 \quad{ }^{* *} \mathrm{p}<.01 \quad{ }^{* * *} \mathrm{p}<.001$

Tablo 3.'te görüldüğü gibi, cinsiyet değişkenine göre, “Öğretmenlerin Sanal Sınıf Yönetimi Yeterliği Ölçeği", genel ve alt boyut toplam aritmetik ortalamaları içinde sadece "sanal sinıf içi etkinliğe" yönelik yeterlikler alt boyutunda istatistiksel açıdan anlamlı farklılıklar meydana gelmiştir. Kadın öğretmenlerin "sanal sınıf içi etkinlikleri" yönetme yeterlikleri $(\bar{x}=4.13)$; erkek öğretmenlere göre $(\overline{\mathrm{x}}=3.94)$ istatistiksel açıdan anlamlı derecede daha yüksektir $(\mathrm{p}<.01)$. Cinsiyet değişkeni, öğretmenlerin sanal sınıf içi etkinliklere ilişkin yeterlik algıları toplam varyansının \% 2.1'ini karşılamaktadır.

Öğretmenlerin eğitim durumu değişkenine göre “Öğretmenlerin Sanal Sınıf Yönetimi Yeterliği Ölçeği" için yapılan ilişkisiz grup " $t$ " testi sonuçları Tablo 4'te sunulmuştur.

Tablo 4. Eğitim Durumu Değişkenine Göre Öğretmenlerin Sanal Sınıf Yönetimi Yeterliği Ölçeği Genel ve Alt Boyut Toplam Puan Ortalamaları Arasındaki Farklar

\begin{tabular}{llcccccc}
\hline Alt Boyutlar & Eğitim Durumu & $\mathbf{N}$ & $\overline{\mathrm{X}}$ & $\mathbf{S S}$ & $\mathbf{t}$ & $\mathbf{s d}$ & $\mathbf{p}$ \\
\hline Öğrencilerle ilişkiler & Lisans & 279 & 3,5982 &, 65822 & 1,529 & 327 &, 127 \\
& Lisans üstü & 50 & 3,4382 &, 80240 & & & \\
Sanal sınıf içi etkinlik & Lisans & 279 & 4,0963 &, 54462 & 1,070 & 327 &, 286 \\
& Lisans üstü & 50 & 4,0050 &, 61599 & & & \\
Sanal sınıf yönetimi & Lisans & 279 & 3,6036 &, 68372 &,- 004 & 327 &, 997 \\
& Lisans üstü & 50 & 3,6040 &, 72786 & & & \\
Toplam & Lisans & 279 & 3,7661 &, 50622 & 1,044 & 327 &, 297 \\
& Lisans üstü & 50 & 3,6824 &, 60335 & & & \\
\hline
\end{tabular}

${ }^{*} \mathrm{p}<.05 \quad{ }^{* *} \mathrm{p}<.01 \quad{ }^{* * *} \mathrm{p}<.001$

Tablo 4.'te görüldüğü gibi, öğretmenlerin eğitim durumu değişkenine göre “Öğretmenlerin Sanal Sınıf Yönetimi Yeterliği Ölçeği", genel ve alt boyut toplam aritmetik ortalamaları arasında hiçbirinde anlamlı bir farklılık bulunamamıştır. Lisans ve lisansüstü eğitim alanlara göre Öğretmenlerin Sanal Sınıf Yönetimi Yeterliği Ölçeği genel ve alt boyut toplam aritmetik ortalamaları birbirine yakındır. Branş değişkenine göre “Öğretmenlerin Sanal Sınıf Yönetimi Yeterliği Ölçeği" genel ve alt boyut toplam puan ortalamaları arasındaki farklar (ANOVA) Tablo 5.'te verilmiştir. 
Tablo 5. Branş Değişkenine Göre Öğretmenlerin Sanal Sınıf Yönetimi Yeterliği Ölçeği Genel ve Alt Boyut Toplam Puan Ortalamaları Arasındaki Farklar (ANOVA)

\begin{tabular}{llcccccc}
\hline Alt Boyutlar & Branş & N & $\bar{X}$ & SS & sd & F & p \\
\hline Öğrencilerle ilişkiler & Okul Öncesi & 49 & 3,3970 &, 7806 & $2-326$ & 3,39 &, $035^{*}$ \\
& Sinıf Öğretmenliği & 135 & 3,6761 &, 6978 & & & \\
& Branş Öğretmenliği & 145 & 3,5386 &, 6205 & & & \\
& Toplam & 329 & 3,5739 &, 6831 & & & \\
Sanal sınıf içi etkinlik & Okul Öncesi & 49 & 4,1888 &, 5267 & $2-326$ & 6,28 &, $002^{* *}$ \\
& Sinıf Öğretmenliği & 135 & 4,1731 &, 5034 & & & \\
& Branş Öğretmenliği & 145 & 3,9621 &, 5913 & & & \\
Sanal sınıf yönetimi & Toplam & 329 & 4,0824 &, 5560 & & & \\
& Okul Öncesi & 49 & 3,0490 &, 8057 & $2-326$ & 21,1 &, $000^{* * *}$ \\
& Sınıf Öğretmenliği & 135 & 3,7259 &, 6189 & & & \\
Toplam & Branş Öğretmenliği & 145 & 3,6772 &, 6210 & & & \\
& Toplam & 329 & 3,6036 &, 6894 & & & \\
& Okul Öncesi & 49 & 3,5449 &, 5855 & $2-326$ & 7,09 & \\
& Sinıf Öğretmenliği & 135 & 3,8584 &, 4967 & & & \\
& Branş Ö̆ğretmenliği & 145 & 3,7260 &, 5008 & & & \\
& Toplam & 329 & 3,7533 &, 5220 & & & \\
\hline
\end{tabular}

${ }^{* *} \mathrm{p}<.01 \quad{ }^{* * *} \mathrm{p}<.001$

Tablo 5.'te görüldüğü gibi, öğretmenlerin branş durumu değişkenine göre “Öğretmenlerin Sanal Sınıf Yönetimi Yeterliği Ölçeği", genel ve alt boyut toplam aritmetik ortalamaları( $\overline{\mathrm{x}})$ arasında farklılığı sınamak için yapılan tek yönlü varyans analizinde (ANOVA) istatistiksel açıdan anlamlı farklılıklar meydana gelmiştir. Sınıf öğretmenliği bölümü öğretmenlerinin öğrencilerle ilişkisi, en yüksek düzeydedir. Sanal sınıf içi etkinlik boyutunda okul öncesi öğretmenleri en yüksek ortalamaya sahiptir. Sanal sinıf yönetimi ve toplam puanlarda yine sınıf öğretmenleri en yüksek ortalamaya sahip olmuştur. Branş değişkeni, öğrencilerle ilişkiler alt boyutun varyansının \%2'sini, sanal sınıf içi etkinlikleri alt boyutun \%3,7'sini, sanal sınıf yönetiminin \%11,5'ini ve toplam puanların \%4,2'sini karşılamaktadır.

Branş değişkenine göre çalışma grubunun Öğretmenlerin Sanal Sınıf Yönetimi Yeterliği Ölçeği genel ve alt boyut toplam puanlarının varyans farklılıkları için yapılan Levene's testinde istatistiksel açıdan hiçbir anlamlı farklılık bulunamamıştır ( $>$ >.05). Hesaplanan puan varyansları homojendir. ANOVA'da elde edilen bu anlamlı farklılıklar üzerine ikili gruplar arasındaki farklılıkları belirlemek üzere alt boyut ve toplamda varyansların homojen olması nedeniyle bu alt boyutlar için post-hoc tekniklerden Scheffe testi kullanılmıştır.

Öğrencilerle ilişkiler alt boyutunda sınıf öğretmenlerinin Öğretmenlerin Sanal Sınıf Yönetimi Yeterliği Ölçeği öğrencilerle ilişkiler puan ortalaması, okul öncesi öğretmenlerinden anlamlı düzeyde daha yüksektir $(p<, 05)$. Sanal sınıf içi etkinlikler yeterliğinde okul öncesi $(p<, 05)$ ve sinıf öğretmenlerinin puan ortalaması $(p<, 01)$, branş öğretmenlerinden daha yüksektir. Sanal sınıf yönetiminde, okul öncesi öğretmenlerinin puan ortalaması, sınıf ve branş öğretmenlerinden anlamlı derecede daha düşüktür $(\mathrm{p}<, 001)$. Sınıf öğretmenlerinin Öğretmenlerin Sanal Sınıf Yönetimi Yeterliği Ölçeği toplam puan ortalaması, okul öncesi öğretmenlerinden anlamlı düzeyde daha yüksektir $(\mathrm{p}<, 001)$.

Çalışma grubunun sanal sınıf deneyimi değişkenine göre “Öğretmenlerin Sanal Sınıf Yönetimi Yeterliği Ölçeği" için yapılan ilişkisiz grup " $t$ " testi sonuçları Tablo 6' da sunulmuştur. 
Tablo 6. Sanal Sınıf Deneyimi Değişkenine Göre Öğretmenlerin Sanal Sınıf Yönetimi Yeterliği Ölçeği Genel ve Alt Boyut Toplam Puan Ortalamaları Arasındaki Farklar

\begin{tabular}{llcccccc}
\hline \multirow{2}{*}{ Alt Boyutlar } & Sanal Sinıf & & & & & & \\
& Deneyimi & $\mathbf{N}$ & $\bar{X}$ & SS & $\mathbf{t}$ & sd & p \\
\hline Öğrencilerle ilişkiler & Var & 115 & 3,7597 &, 61105 & 3,684 & 327 &, $000^{* * *}$ \\
& Yok & 214 & 3,4741 &, 70015 & & & \\
Sanal sınıf içi etkinlikler & Var & 115 & 4,1989 &, 51960 & 2,814 & 327 &, $005^{* *}$ \\
& Yok & 214 & 4,0199 &, 56597 & & & \\
Sanal sınıf yönetimi & Var & 115 & 3,8626 &, 50705 & 5,188 & 327 &, $000^{* * *}$ \\
& Yok & 214 & 3,4645 &, 73398 & & & \\
Toplam & Var & 115 & 3,9404 &, 44590 & 4,932 & 327 &, $000^{* * *}$ \\
& Yok & 214 & 3,6528 &, 53304 & & & \\
\hline
\end{tabular}

${ }^{*} \mathrm{p}<.05 \quad{ }^{* *} \mathrm{p}<.01 \quad{ }^{* * *} \mathrm{p}<.001$

Tablo 6.'da görüldüğü gibi, öğretmenlerin sanal sınıf deneyimi değişkenine göre “Öğretmenlerin Sanal Sınıf Yönetimi Yeterliği Ölçeği” genel ve alt boyut toplam aritmetik ortalamaları arasında hepsinde anlamlı bir farklılık bulunmuştur $(\mathrm{p}<, 001)$. Daha önce sanal sınıf deneyimi olan öğretmenlerin "Öğretmenlerin Sanal Sınıf Yönetimi Yeterliği Ölçeği”, genel ve alt boyut toplam aritmetik ortalamaları, sanal sinıf deneyimi olmayanlardan anlamlı derecede daha yüksektir. Sanal sınıf deneyimi değişkeni, öğrencilerle ilişkiler alt boyutu varyansının \% 4'ünü, sanal sinıf içi etkinlikleri alt boyutunun \% 2,4'ünü, sanal sınıf yönetiminin \%7,6'sını ve toplam puanların \% 6,9'unu karşılamaktadır.

Kıdem değişkenine göre, "Öğretmenlerin Sanal Sınıf Yönetimi Yeterliği Ölçeği”" genel ve alt boyut toplam puan ortalamaları arasındaki farklara (ANOVA) ilişkin sonuçlar Tablo 7.'de verilmiştir. 
Tablo 7. Kıdem Değişkenine Göre Öğretmenlerin Sanal Sınıf Yönetimi Yeterliği Ölçeği Genel ve Alt Boyut Toplam Puan Ortalamaları Arasındaki Farklar (ANOVA)

\begin{tabular}{|c|c|c|c|c|c|c|c|}
\hline Alt Boyutlar & Kidem & $\mathbf{N}$ & $\overline{\mathrm{X}}$ & SS & sd & $\mathbf{F}$ & $\mathbf{p}$ \\
\hline \multirow[t]{7}{*}{ Öğrencilerle ilişkiler } & $1-5$ y1l & 47 & 3,4855 & ,68406 & $5-323$ & ,598 & ,701 \\
\hline & 6-10 yıl & 85 & 3,6021 & 68992, & & & \\
\hline & $11-15$ y1l & 62 & 3,4839 & 64740 & & & \\
\hline & $16-20$ yıl & 47 & 3,6286 & 66503 & & & \\
\hline & $21-25$ y1l & 60 & 3,6091 & 75065 & & & \\
\hline & 26 yıl ve üstü & 28 & 3,6688 & 63863 & & & \\
\hline & Toplam & 329 & 3,5739 & 68316 & & & \\
\hline \multirow[t]{7}{*}{ Sanal sınıf içi etkinlikler } & $1-5$ yıl & 47 & 4,1250 & ,45594 & $5-323$ & 470 & 799 \\
\hline & $6-10 \mathrm{yll}$ & 85 & 4,1338 & ,45431 & & & \\
\hline & 11-15 y1l & 62 & 4,0968 & 49816 & & & \\
\hline & $16-20$ y1l & 47 & 4,0133 & 79964 & & & \\
\hline & $21-25$ y1l & 60 & 4,0333 & 60316 & & & \\
\hline & 26 yıl ve üstü & 28 & 4,0446 & ,53599 & & & \\
\hline & Toplam & 329 & 4,0824 & ,55602 & & & \\
\hline \multirow[t]{7}{*}{ Sanal sınıf yönetimi } & $1-5$ yil & 47 & 3,6553 & ,72676 & $5-323$ & 1,06 & ,378 \\
\hline & $6-10$ yıl & 85 & 3,6376 & 62144 & & & \\
\hline & $11-15$ y1l & 62 & 3,4323 & ,76153 & & & \\
\hline & $16-20$ y1l & 47 & 3,5957 & ,59635 & & & \\
\hline & $21-25$ y1l & 60 & 3,6933 & 75596 & & & \\
\hline & 26 y1l ve üstü & 28 & 3,6143 & 64390 & & & \\
\hline & Toplam & 329 & 3,6036 & 68946 & & & \\
\hline \multirow[t]{7}{*}{ Toplam } & 1-5 yıl & 47 & 3,7553 & 48192 & $5-323$ & ,435 & 824 \\
\hline & 6-10 yıl & 85 & 3,7912 & ,46122 & & & \\
\hline & $11-15$ y1l & 62 & 3,6710 & 48979 & & & \\
\hline & $16-20$ y1l & 47 & 3,7459 & ,57607 & & & \\
\hline & $21-25$ y1l & 60 & 3,7786 & 62412 & & & \\
\hline & 26 y1l ve üstü & 28 & 3,7759 & ,52151 & & & \\
\hline & Toplam & 329 & 3,7533 & ,52200 & & & \\
\hline
\end{tabular}

${ }^{*} \mathrm{p}<.05 \quad{ }^{* *} \mathrm{p}<.01 \quad{ }^{* * *} \mathrm{p}<.001$

Tablo 7.'de görüldüğü gibi, öğretmenlerin kıdem değişkenine göre, “Öğretmenlerin Sanal Sınıf Yönetimi Yeterliği Ölçeği" genel ve alt boyut toplam aritmetik ortalamaları arasında farklılığı sınamak için yapılan tek yönlü varyans analizinde (ANOVA) istatistiksel açıdan hiçbir anlamlı farklılık meydana gelmemiştir. Farklı kıdem düzeyine sahip öğretmenlerin sanal sinıf yönetimi yeterlikleri birbirine benzer düzeydedir.

Görev yapılan kurum değişkenine göre, öğretmenlerin sanal sınıf yönetimi yeterlikleri özelliklerini algılamalarını sınamak için grupların ölçek genel ve alt boyut ortalamaları arasındaki farklılığ 1 belirlemek üzere tek yönlü varyans analizi(ANOVA) yapılmış ve sonuçları Tablo 8'de verilmiştir. 
Tablo 8. Görev Yapılan Kurum Değişkenine Göre Öğretmen Sanal Sınıf Yönetimi Yeterliği Ölçeği Genel ve Alt Boyut Toplam Puan Ortalamaları Arasındaki Farklar (ANOVA)

\begin{tabular}{llcccccc}
\hline Alt Boyutlar & Branş & N & $\bar{X}$ & SS & sd & F & p \\
\hline \multirow{4}{*}{ Öğrencilerle İlişkiler } & Okul Öncesi & 42 & 3,4805 &, 8337 & $2-326$ & 3,58 &, $014^{*}$ \\
& İlkokul & 142 & 3,6408 &, 6865 & & & \\
& Ortaokul & 54 & 3,7424 &, 6093 & & & \\
& Lise & 91 & 3,4126 &, 6104 & & & \\
& Toplam & 329 & 3,5739 &, 6831 & & &, $000^{* * *}$ \\
& Okul Öncesi & 42 & 4,1786 &, 5217 & $2-326$ & 7,15 & \\
& İlkokul & 142 & 4,2033 &, 4916 & & & \\
Sanal sinıf içi etkinlik & Ortaokul & 54 & 4,0278 &, 4182 & & & \\
& Lise & 91 & 3,8819 &, 6716 & & & \\
& Toplam & 329 & 4,0824 &, 5560 & & & \\
& Okul Öncesi & 42 & 3,0857 &, 8452 & $2-326$ & 11,8 & \\
& İlkokul & 142 & 3,6732 &, 6433 & & & \\
& Ortaokul & 54 & 3,8556 &, 5472 & & & \\
& Lise & 91 & 3,5846 &, 6409 & & & \\
& Toplam & 329 & 3,6036 &, 6894 & & & \\
& Okul Öncesi & 42 & 3,5816 &, 6239 & $2-326$ & 5,81 & \\
& İlkokul & 142 & 3,8391 &, 4870 & & & \\
& Ortaokul & 54 & 3,8753 &, 4328 & & & \\
& Lise & 91 & 3,6264 &, 5321 & & & \\
& Toplam & 329 & 3,7533 &, 5220 & & & \\
\hline
\end{tabular}

${ }^{* *} \mathrm{p}<.01 \quad{ }^{* * *} \mathrm{p}<.001$

Tablo 8.'de görüldüğü gibi, öğretmenlerin görev yapılan kurum değişkenine göre “Öğretmenlerin Sanal Sınıf Yönetimi Yeterliği Ölçeği” genel ve alt boyut toplam aritmetik ortalamaları arasında farklılığı sinamak için yapılan tek yönlü varyans analizinde (ANOVA) istatistiksel açıdan en az ,05 düzeyinde anlamlı farklılıklar meydana gelmiştir. Görev yapılan kurum değişkeni, öğrencilerle ilişkiler alt boyutun varyansının \% 3.2'sini, sanal sınıf içi etkinlikleri alt boyutun \% 6,2'sini, sanal sinıf yönetiminin \% 9.9'nu ve toplam puanların \% 5,1'ini karşılamaktadır. ANOVA'dan elde edilen bu anlamlı farklılıklar üzerine ikili gruplar arasındaki farklılıkları belirlemek üzere alt boyut ve toplamda varyansların homojen olması nedeniyle bu alt boyutlar için post-hoc tekniklerden Scheffe testi kullanılmıştır.

Buna göre, "öğrencilerle ilişkiler" alt boyutunda ortaokul öğretmenlerinin puan ortalaması, lise öğretmenlerinden anlamlı düzeyde daha yüksektir $(\mathrm{p}<, 05)$. "Sanal sınıf içi etkinlikler" yeterliğinde okul öncesi $(p<, 05)$ ve sınıf öğretmenlerinin puan ortalaması $(p<, 001)$, lise öğretmenlerinden daha yüksektir. "Sanal sinif yönetimi" boyutunda, okul öncesi öğretmenlerinin puan ortalaması, ilkokul, ortaokul ve lise öğretmenlerinden anlamlı derecede daha düşüktür $(p<, 001)$. Sınıf öğretmenlerinin “Öğretmenlerin Sanal Sınıf Yönetimi Yeterliği Ölçeği" toplam puan ortalaması, okul öncesi öğretmenlerinden anlamlı düzeyde daha yüksektir $(\mathrm{p}<, 05)$. İlkokul ve ortaokul öğretmenlerinin “Öğretmenlerin Sanal Sınıf Yönetimi Yeterliği Ölçeği" toplam puan ortalaması, okul öncesi ve lise öğretmenlerinden anlamlı düzeyde daha yüksektir $(\mathrm{p}<, 05)$.

\section{Tartışma, Sonuç ve Öneriler}

Araştırma sonucunda, öğretmenlerin sanal sınıf yönetimi yeterliklerinin genel olarak "katılıyorum" düzeyinde olduğu görülmektedir. Diğer bir ifadeyle, öğretmenlerin sanal sinıf 
yönetimindeki yeterliklerinin yüksek düzeyde olduğu söylenebilir. "Öğrencilerle ilişkiler", "sanal sınıf içi etkinlikler" ve "sanal sınıf yönetimi" alt boyutlarında da "katıllyorum" düzeyindedir. Bu sonuçlar, öğretmenlerin sanal sınıf yönetimi konusunda kendilerine yeterli düzeyde güvendiklerini ve kendilerini yeterli gördüklerini göstermektedir. Bu sonuçlar, öğretmenlerin öğretim ortamı, öğretimin yönetimi, davranışların yönetimi, etkileşim, motivasyon, teknolojinin yönetimi, özel gereksinimli öğrencilerin yönetimi ve zaman yönetimi olarak sıralanan sanal sınıf yönetimi boyutlarında (Can, 2020a) kendilerini yeterli gördükleri şeklinde yorumlanabilir.

Araştırma sonucuna göre, öğretmenlerin ölçeğin "öğrencilerle ilişkiler" alt boyutunda öğrencilerle etkili bir iletişim kurabildikleri, pekiştireç ve geribildirim sağlayabildikleri, zamanı etkili kullanabildikleri, öğretme-öğrenme etkinliklerini etkili yönetebildikleri söylenebilir. Benzer şekilde, sanal sınıflarda öğreten ile öğrenenler arasındaki etkili bir iletişimin ders başarısını olumlu etkilediği (Yaşlıca, 2020; Yılmazsoy, Özdinç ve Kahraman, 2018), ancak sanal sınıflarda bu etkileşimin öğrenci sayısı ile doğrudan ilişkili olduğu (Kaya ve Ağaoğlu, 2013), bu yüzden etkileşimi artırabilmek için sanal sınıflardaki öğrenci sayısının maksimum 24 kişi ile sınırlandırılması (Stern, 2004), öğrencilere gönderilecek mesaj, duyuru ve isteklerin açık, anlaşılır ve kısa olması (Can, 2020a) ve sanal ortamda öğrenciler arasında topluluk bilinci oluşturulması gerektiği (Berry, 2019) önerilmektedir. Araştırma sonucunda öğretmenlerin zamanı etkili kullanabilmeleri, sanal sınıflarda zaman yönetimi konusunda kendilerini yeterli gördüklerini göstermektedir. Benzer şekilde, Yılmazsoy, Özdinç ve Kahraman'ın (2018) araştırma sonucuna göre, sanal sınıflarda zamanın verimli kullanıldığ belirtilmektedir. Ancak, araştırma sonuçlarından farklı olarak Stern'e (2004) göre, öğrenci başarısını ölçme ve değerlendirme, öğrenenlerin ders katılım durumlarının kontrolü, ödevlerin ve belgelerin sisteme yüklenmesi, öğretenlerin iş yükünü artırmakta ve daha çok zaman ihtiyacı doğurmaktadır. Geleneksel sınıflarda olduğu gibi, sanal sınıfların yönetimindeki en önemli boyutlardan biri etkili zaman yönetimidir. Özellikle, sanal derslerin gün, saat ve süre bakımından planlanması, ders öncesi materyal ve sunum hazırlıklarının yapılması, gerekli bilgi ve belgelerin önceden sisteme yüklenmesi, ders oturumlarının zamanında başlatılması (Can, 2020a), ajanda ve takvime hatırlatmalar eklenmesi (Kaya, 2011), öğretmenlerin sanal sınıflarda etkili zaman yönetimine olumlu katkılar sağlayacaktır.

Ayrıca, araştırma sonucu öğretmenlerin sanal sınıflarda öğrencilerin derslere katılımını sağlayabildikleri, soru sorma ve tartışmalara katılma gibi süreçleri etkili yönetebildiklerini, sanal ortamda kuralları öğrencilere eşit olarak uygulayabildiklerini göstermektedir. Araştırma sonuçları ile benzer şekilde, Franklin, \& Harrington'ın (2019) belirttiği gibi, etkili bir sınıf yönetiminde öğrenci katılımının sağlanması, öğrenci ve öğretmenlerin rol ve sorumluluklarının paylaşılması büyük rol oynamaktadır. Bunun için etkili bir sınıf planlaması ve yönetimi ile öğrencilerin öğrenme işi ile meşgul olmalarının sağlanması önerilmektedir.

Araştırma sonucuna göre, öğretmenler sanal sinıflarda öğrencilere rahatlıkla müdahale edebilmekte, öğrenci başarısını ölçme ve değerlendirmede farklı yöntemleri kullanabilmekte ve öğrencilerin ihtiyaç duydukları rehberlik hizmetini sağlayabilmektedir. Araştırma sonucuna göre, öğretmenlerin istenmeyen öğrenci davranışlarına rahatlıkla müdahale edebilmesi, Atıcı'nın (2004) belirttiği gibi, sanal öğrenme çevresinin geliştirilebilmesi, öğrenci davranışlarının denetim altına alınması ile mümkün olmaktadır. Bunun için öğretmenlerin sanal sınıf yönetiminde yeterli olmaları veya ihtiyaç halinde yeterliklerinin sağlanması gerekmektedir. 
Araştırma sonucu ile benzer şekilde sanal sınıflarda öğrenci başarısını ölçme ve değerlendirmede farklı yöntemlerin kullanılmasının (Can, 2020a; Kaya, 2011), sanal sınıfların etkililiği bakımından önemli olduğu belirtilmektedir. Ancak, uzaktan öğrenme ortamlarında öğrenim gören öğrencilerin farklı gelecek beklentileri olması, onların yüksek beklentilerle motive edilmesini zorlaştırmaktadır (Çakıroğlu, 2014). Sanal ortamda öğrenen ve öğretenlerin farklı fiziksel mekânlarda bulunması iletişim problemlerine, öğrenenlerin sosyal ve duygusal yalnızlık yaşamalarına neden olabilir (Can, 2020a, s.276). Bu nedenlerle, sanal sinıf ortamlarında öğrenenlerin motivasyonunu sağlayabilmek için öğrenenlerde sorumluluk üstlenme arzusu geliştirme (Stern, 2004), sanal sınıf ortamının dikkat çekici olması (Kaya, 2011), sesli ve görüntülü olması (Akçay, 2018), öğrenenlere ders öncesinde, ders sırasında ve ders sonunda sözlü, yazılı ve görsel mesajlar sunulması, gerektiğinde ihtiyacı olan özellikle küçük yaş grubundaki ve özel gereksinimli öğrenenlerin aileleri ile sanal ortamda bireysel ve ortak görüşmeler yapılması (Can, 2020a, s.276) faydalı görülmektedir.

Araştırma sonucuna göre, öğretmenler ölçeğin "sanal sınıf içi etkinlikler" boyutunda kendilerini yeterli görmektedirler. Bu sonuç, öğretmenlerin sanal ortamlarda öğrencilerin gerekli teknolojik araçlara sahip olma yeterliğine önem verdiklerini, sınıf kurallarını öğrencilerle birlikte belirlediğini, sanal sınıf oturumlarını planlarken öğrencilerin ihtiyaç ve beklentilerini dikkate aldıklarını, sanal sınıf dersleri ile ilgili duyuruları önceden öğrencilere yaptıklarını göstermektedir. Araştırma sonuçları ile benzer şekilde, Franklin, \& Harrington'ın (2019), sınıf kuralları ve öğretmen beklentilerinin dönem başında ortaklaşa düzenlenerek paylaşılması ve öğretilmesinin önemli olduğunu belirtmektedir. Can'a (2020a, s.271) göre, sanal sınıf dersleri öncesinde ders oturum saatleri, ders süreleri, katılımcı grupların özellikleri, ders materyalleri ile ders başarısını ölçme ve değerlendirmeye ilişkin standartlar önceden planlanarak katılımcılarla paylaşılmalıdır. Sanal sınıflarda da, geleneksel sınıflarda olduğu gibi herkesin uyması gereken kurallar olmalıdır (Yılmazsoy, Özdinç ve Kahraman, 2018). Sanal sınıf kuralları, öğretenler tarafından öğrenenlerin ihtiyaç ve beklentileri esas alınarak önceden e-posta, duyuru vb. iletişim kanalları ile duyurulmalı ve birlikte belirlenmelidir (Can, 2020a, s.272).

Ayrıca, araştırma sonucu öğretmenlerin sanal sınıflarda önceden ortaya çıabilecek olumsuzluklara karşı hazırlıklı olduklarını, ders sürelerini belirlemede öğrenci özelliklerini dikkate aldıklarını, ders içeriklerinin güncel ve dikkat çekici olmasına dikkat ettiklerini, öğrencilerin teknolojik araçları etkili kullanabilmeleri konusunda gerekli desteği sağlayabildiklerini göstermektedir. Sanal sinıflarda öğretimin teknoloji tabanlı olarak gerçekleştirilmesi nedeniyle, öğretmenlerin öğrencilerin teknolojik yeterliklerine önem vermesi ve gerekli desteği sağlamaları büyük önem taşımaktadır. Çünkü, sanal sınıflarda kullanılan teknolojik araçların erişilebilir, esnek, kullanımının kolay, güvenli ve teknik destek sunulabilir olması (Kaya, 2011), internet güvenliği olması ve öğretenlerin öğrenenlere rehberlik ve yardım sağlayabilecek beceriye sahip olması (Can, 2020a), öğretenlerin teknolojik araçları kullanma ve yönetme konusunda yeterli olması (Şad ve Yokuş, 2018), sanal sınıf uygulamalarını olumlu etkilemektedir.

Araştırma sonucuna göre, öğretmenlerin sanal sınıfların yönetiminde gerekli olan teknolojiyi kullanma yeterliğine sahip oldukları, sanal dersler öncesinde teknolojik yönden gerekli hazırlıkları yaptıkları ve sanal sınıflarda farklı yöntem ve teknikleri kullanabildikleri söylenebilir. Araştırma sonuçları ile benzer şekilde, sanal sınıflarda farklı yöntem ve teknik kullanımının öğrenci başarısına olumlu katkı sağladığı (Yılmazsoy, Özdinç ve Kahraman, 
2018; Kaya, 2011) belirtilmektedir. Martin, Parker, \& Ndoye (2011) eş zamanlı sanal bir sınıfın başarısında teknolojik olanakların kullanımı ve kurulumunun kolay, kullanılabilir ve kesintisiz erişime uygun olması gerektiğini belirtmektedir. Ancak, Karaman, Aydemir, Küçük, \& Yıldırım'ın (2013) araştırma sonucuna göre, sanal sınıf oturumları sırasında yaşanan teknik sorunlar katılımcları rahatsız etmekte ve sınıfın verimliliğini düşürmektedir. Bu durumun aynı zamanda öğretmenlerin de sanal sınıf performansları üzerinde olumsuz etkiler yaratabileceği dikkate alınarak sanal sınıfların teknik altyapılarının sağlıklı oluşturulması gerektiği söylenebilir. Araştırma sonucuna göre, öğretmenlerin ölçeğin "sanal sınıf yönetimi" boyutunda kendilerini yeterli olarak algılamaları, daha önceden almış oldukları eğitimin yeterli olduğunu ve buna bağlı olarak da sanal sınıf yönetimi konusunda kendilerine güvendiklerini göstermektedir. Araştırma sonuçları bir bütün olarak değerlendirildiğinde, Can'ın (2020a, s.266) belirttiği gibi, sanal sınıfların etkili yönetimi için sanal ortamda teknolojik araçların, yöntem ve tekniklerin seçilmesi, organize edilmesi ve etkili olarak kullanılması, öğretim materyallerinin öğrenenlerin ihtiyaç ve beklentilerine uygun olarak hazırlanması ve kullanılması, öğrenenlerle etkileşim sağlanması ve öğrenme ortamının düzenlenmesi büyük önem taşımaktadır.

Araştırma sonucunda, öğretmenlerin görüşleri demografik değişkenlere göre incelendiğinde, cinsiyet değişkenine göre, "sanal sınıf içi etkinliklere" yönelik yeterlikler alt boyutunda anlamlı farklılıklar meydana gelmiştir. Buna göre, kadın öğretmenlerin "sanal sınıf içi etkinlikleri" yönetme yeterlikleri, erkek öğretmenlere göre anlamlı derecede daha yüksektir. Burada kadın öğretmenlerin iç organizasyon konusunda yani yakın çevre olanaklarını harekete geçirmede daha yetenekli olduklarını söylemek mümkündür. Eğitim durumu değişkenine göre, "Öğretmenlerin Sanal Sınıf Yönetimi Yeterliği Ölçeği", genel ve alt boyut toplam aritmetik ortalamaları arasında hiçbirinde anlamlı bir farklılık bulunamamıştır. Bu sonuç, eğitim durumunun öğretmenlerin sanal sınıf yönetimi yeterliklerine ilişkin algılamalarını etkileyen bir faktör olmadığını ortaya koymaktadır. Branş durumu değişkenine göre, "Öğretmenlerin Sanal Sınıf Yönetimi Yeterliği Ölçeği”, genel ve alt boyut toplam puanları arasında anlamlı farklılıklar meydana gelmiştir. Buna göre, sınıf öğretmenlerinin "Öğretmenlerin Sanal Sınıf Yönetimi Yeterliği Ölçeği”, "öğrencilerle ilişkiler" puan ortalaması, okul öncesi öğretmenlerinden anlamlı düzeyde daha yüksektir. "Sanal sinıf içi etkinlikler" yeterliğinde okul öncesi ve sinıf öğretmenlerinin puan ortalaması, branş öğretmenlerinden daha yüksektir. "Sanal sinıf yönetimi", boyutunda ise okul öncesi öğretmenlerinin puan ortalaması, sınıf ve branş öğretmenlerinden anlamlı derecede daha düşüktür. Sınıf öğretmenlerinin "Öğretmenlerin Sanal Sınıf Yönetimi Yeterliği Ölçeği” toplam puan ortalaması, okul öncesi öğretmenlerinden anlamlı düzeyde daha yüksektir. Bu sonuç, sınıf öğretmenlerinin öğretim yaptığı sınıf düzeyi, hizmet öncesi öğretmen eğitiminde yeterli eğitimi alma durumları ve kendilerini yetiştirmeleri ile açılanabilir. Ayrıca, okul öncesi öğretmenlerinin ise bu gruba yeterli öğretim hizmeti yapma durumları, okul öncesi dönemdeki öğrenciler için sanal sınıf uygulamasının var olup olmadığı, süresi, etkinliğin türü gibi faktörlerle açılanabilir.

Sanal sınıf deneyimi değişkenine göre, "Öğretmenlerin Sanal Sınıf Yönetimi Yeterliği Ölçeği” genel ve alt boyut toplam puanları arasında hepsinde anlamlı farklılıklar bulunmuştur. Buna göre, daha önce sanal sınıf deneyimi olan öğretmenlerin "Öğretmenlerin Sanal Sınıf Yönetimi Yeterliği Ölçeği", genel ve alt boyut puan ortalamaları, sanal sınıf deneyimi olmayan öğretmenlerden anlamlı derecede daha yüksektir. Bu sonuç, araştırmanın en önemli 
sonuçlarından biri olarak öğretmenlerin daha önceden sanal sınıf uygulamalarını kullanma deneyiminin sanal sınıf uygulamalarında öğretmenlerin yeterliği üzerinde önemli bir etkiye sahip olduğunu göstermektedir. Kıdem değişkenine göre, öğretmenlerin “Öğretmenlerin Sanal Sınıf Yönetimi Yeterliği Ölçeği" genel ve alt boyut toplam puanları arasında anlamlı farklılıklar meydana gelmemiştir. Görüldüğü gibi, kıdem sanal sınıf yeterliğine ilişkin öğretmen görüşlerini etkileyen önemli bir değişken değildir. Araştırma sonuçları, öğretmenlerin sanal sınıf yönetimi yeterliklerinde kıdem değişkeninden daha çok öğretmenlerin sanal sınıf deneyiminin önemli olduğunu ortaya koymaktadır. Bu sonuca dayalı olarak, öğretmenlerin sanal sınıf deneyimlerinin gerek hizmet öncesi eğitimlerde gerekse hizmet içi eğitimlerde geliştirilmesinin gerekli ve önemli bir konu olduğu belirtilebilir. Öğretmenlerin sanal sınıf deneyimleri bu şekilde geliştirilerek sanal sınıf yönetimi yeterlikleri de artırılabilir. Çünkü, Can ve Arslan'ın da (2018) belirttiği gibi, öğretmenlerin sınıf yönetimindeki bilgi, beceri ve tutumlarının yanında deneyimleri de sinıf yönetimi yeterliklerini önemli derecede etkilemektedir.

Öğretmenlerin görev yapılan kurum değişkenine göre, “Öğretmenlerin Sanal Sınıf Yönetimi Yeterliği Ölçeği" genel ve alt boyut toplam puanları arasında anlamlı farklılıklar meydana gelmiştir. Buna göre, "öğrencilerle ilişkiler" alt boyutunda ortaokul öğretmenlerinin puan ortalaması, lise öğretmenlerinden anlamlı düzeyde daha yüksektir. "Sanal sınıf içi etkinlikler" yeterliğinde okul öncesi ve sınıf öğretmenlerinin puan ortalaması, lise öğretmenlerinden daha yüksektir. "Sanal sınıf yönetimi" boyutunda ise okul öncesi öğretmenlerinin puan ortalaması, ilkokul, ortaokul ve lise öğretmenlerine göre anlamlı derecede daha düşüktür. Sınıf öğretmenlerinin "Öğretmenlerin Sanal Sınıf Yönetimi Yeterliği Ölçeği" toplam puan ortalaması, okul öncesi öğretmenlerinden anlamlı düzeyde daha yüksektir. İlkokul ve ortaokul öğretmenlerinin "Öğretmenlerin Sanal Sınıf Yönetimi Yeterliği Ölçeği” toplam puan ortalaması, okul öncesi ve lise öğretmenlerinden anlamlı düzeyde daha yüksektir. Bu sonuçlar, öğretim kademelerinin türleri, özellikleri ve ilgili döneme yönelik yürütülen sanal sınıf etkinliklerinin özellikleri ile açklanabilir.

Araştırma sonucuna göre, her ne kadar öğretmenler kendilerini sanal sınıf yönetimi konusunda yeterli olarak görseler de Karaman, Aydemir, Küçük, \& Yıldırım'ın (2013) belirttiği gibi, sanal sınıf oturumlarının etkililiği için belirlenen temel bileşenler etkileşim, teknik sağlamlık, zamanlama ve materyal kullanımıdır. Sanal sınıfların etkililiği için sanal sınıflarda aktif katılım, özetleme, dikkat çekme, dersi gerçek yaşamla ilişkilendirme ve müfredat dış1 çalışmaların yararlı olacağı belirtilmektedir. Bu bileşenler ve öğretim yöntemlerinin esas alınmasının öğretmenlerin sanal sınıf yönetimi yeterliklerinin gelişmesine olumlu katkılar sağlayabileceği söylenebilir. Ayrıca, öğretmen adaylarının sınıf yönetimi becerilerini geliştirmede sanal simülasyonlardan yararlanılması (McGarr, 2020), etkileşimli öğretim materyalleri geliştirilmesi ve kullanılması (Yaşlıca, 2020), kaliteli sanal ders içeriklerinin geliştirilmesi (Bilgiç ve Tüzün, 2005), öğrenenlerin teknoloji ve sistem kullanımı konusunda eğitilmesi (Çakıroğlu, 2014), öğretenlerin hizmet öncesi dönemde sanal sınıf yönetimi konusunda yetiştirilmeleri (Asim, Ponners, Bartlett, Parker, \& Star, 2020; Milliken, 2019), sanal ortamlarda öğrenenlerin kolay erişimini sağlayacak yüksek teknolojik araçlar kullanılması (Martin, 2019), öğretmenlerin sanal sınıf yönetimi yeterliklerini geliştirecek ve sanal sınıf yönetiminin etkililiği artacaktır. Ayrıca, Türkiye'de açık ve uzaktan eğitim sisteminin altyapı, erişim, güvenlik, içerik, tasarım, uygulama, kalite, mevzuat ve pedagojik açıdan güçlendirilmesi (Can, 2020b), öğretmenlerin sanal sınıf yönetimi yeterliklerine olumlu katkılar sağlayabilir. Bu araştırmada öğretmenlerin kendi sanal sınıf yönetimi yeterlik düzeylerine 
ilişkin görüşlerinin belirlenmesi araştırmanın bir sınırlılığı olarak belirtilebilir. Bu nedenle, öğretmenlerin sanal sınıf yönetimi yeterliklerini belirlemeye yönelik olarak farklı öğretim kademelerinde okul yöneticileri, öğretmenler, öğrenciler ve veliler gibi farklı katılımcıların görüşlerine göre nicel, nitel ve karma yöntem araştırmaları yürütülebilir.

\section{Kaynakça}

APA. (2020). COVID-19 virtual learning and education: Behavior management. https://www.apa.org/topics/covid-19/education-behavior-management, web adresinden 24 Ocak 2021 tarihinde edinilmiştir.

Akçay, S. (2018). Eş zamanlı sanal sınıf ortamının grafik tasarım dersinde kullanımına yönelik bir uygulama ve öğrenci algıları (Gazi Üniversitesi Örneği). Yüksek Lisans Tezi. Gazi Üniversitesi, Eğitim Bilimleri Enstitüsü, Ankara.

Akkuş, İ. ve Acar, S. (2017). Eş zamanlı öğrenme ortamlarında karşılaşılan teknik sorunların öğretici ve öğrenen üzerindeki etkisini belirlemeye yönelik bir araştırma. İnönü Üniversitesi Ĕ̆itim Fakültesi Dergisi, 18(3), 363-376.

Albrecht, R. (2003). E-learning in hochschulen die implementierung von e-learning an präsenzhochschulen aus hochschuldidaktischer perspektive. Dissertation.de, www.raineralbrecht.de , Dissertation_albrecht_030723, web adresinden 24.01.2021 tarihinde edinilmiştir.

Asim, S., Ponners, P. J., Bartlett, C., Parker, M. A., \& Star, R. (2020). Differentiating Instruction: For middle school students in virtual learning environments. The Delta Kappa Gamma Bulletin: International Journal for Professional Educators, 19-30. http://journal.dkg.org/2020/86-3/files/basichtml/page19.html Erişim tarihi: 03.02.2021

Atıc1, B. (2004). Sosyal bilgi inşasına dayalı sanal öğrenme çevrelerinin öğrenci başarısı ve tutumlarına etkisi. Doktora Tezi. Frrat Üniversitesi, Sosyal Bilimler Enstitüsü, Elazığ.

Aydın, A. (2017). Sinıf yönetimi. Ankara: Pegem Akademi.

Balcı, A. (2004). Sosyal bilimlerde araştırma, yöntem, teknik ve ilkeler. Ankara: Pegem Yayıncılık.

Başar, H. (2011). Sinıf yönetimi. Ankara: Anı Yayıncılık.

Beluce, A. C., \& Oliveira, K. L. D. (2016). Scale of strategies and motivation for learning in virtual environments. Revista Brasileira de Educação, 21(66), 593-611.

Berge, Z. L. (1995). Facilitating computer conferencing: Recommendations from the Field. Educational Technology, 15(1), 22-30.

Berry, S. (2019). Teaching to connect: Community-building strategies for the virtual classroom. Online Learning Journal, 23(1), 164-183.

Bettinger, E.P., Fox, L., Loeb, S., \& Taylor, E. S. (2017). Virtual classrooms: How online college courses affect student success. American Economic Review, 107(9), 2855-2875.

Bigatel, P. M., Ragan, L. C., Kennan, S., May, J., \& Redmond, B. F. (2012). The identification of competencies for online teaching success. Journal of Asynchronous Learning Networks, 16(1), 59-77. https://eric.ed.gov/?id=EJ971040, web adresinden 03.02.2021 tarihinde edinilmiştir.

Bilgiç, H.G. ve Tüzün, H. (2015). Yükseköğretim kurumları web tabanlı uzaktan eğitim programlarında yaşanan sorunlar. $A U A d, 1(3), 26-50$.

Büyüköztürk, Ş. (2011) Sosyal bilimler için veri analizi el kitabı: İstatistik, araştırma deseni SPSS uygulamaları ve yorum. Ankara: Pegem Akademi Yayıncilık.

Byrne, B. M. (1998). Multivariate applications book series.Structural equation modeling with LISREL, PRELIS, and SIMPLIS: Basic concepts, applications, and programming. Lawrence Erlbaum Associates Publishers.

Can, A. (2013). SPSS ile bilimsel araştırma sürecinde nicel veri analizi. Ankara: Pegem A Yayıncllık.

Can, E., \& Gündüz, Y. (2021). Öğretmenlerin sanal sınıf yönetimi yeterliği ölçeği: Geçerlik ve güvenirlik çalışması. Bolu Abant İzzet Baysal Üniversitesi Eğitim Fakültesi Dergisi, 21(2), 574-591.

Can, E. (2020a). Sanal sınıf yönetimi: İlkeler, uygulamalar ve öneriler. Açı̈̈̈̆gretim Uygulamaları ve Araştırmaları Dergisi (AUAd), 6(4), 251-295. 
Can, E. (2020b). Coranavirüs pandemisi ve pedagojik yansımaları: Türkiye'de açık ve uzaktan eğitim uygulamaları. Açıöğretim Uygulamaları ve Araştırmaları Dergisi (AUAd), 6(2), 11-53.

Can, E., \& Arslan, B. (2018). Öğretmenlerin sınıf yönetimi yeterliklerine ilişkin öğrenci görüşleri. Karadeniz Sosyal Bilimler Dergisi, 10(18), 195-2019.

Ceylan, M. (2020). Sanal sınıfların yönetimi. İçinde, Dilruba Kürüm Yapıcıŏglu (Edt.) Pandemi Döneminde Ĕ̆itim (ss. 295-352). Ankara: Anı yayıncılık.

Clark, R. C., \& Kwinn, A. (2007). The new virtual classroom: Evidence based guidelines for synchronous learning. San Francisco: Jossey-Bass.

Çakıroğlu, Ü. (2014). Evaluating students' perspectives about virtual classrooms with regard to seven principles of good practice. South African Journal of Education, 34(2), 1-19.

Çokluk, Ö., Şekercioğlu, G., \& Büyüköztürk, Ş. (2010). Sosyal bilimler için çok değişkenli istatistik. Ankara: Pegem Akademi.

Dikmenli, Y. ve Ünaldı Eser, Ü. (2013). Harmanlanmış öğrenme ve sanal sınıfa dönük öğrenci görüşleri. Amasya Üniversitesi Ĕ̆itim Fakültesi Dergisi, 2(2), 326-347.

Dumont, G., \& Raggo, P. (2018). Faculty perspectives about distance teaching in the virtual classroom. Journal of Nonprofit Education and Leadership, 8(1), 41-61.

Erden, M. (2005). Sınıf yönetimi. Ankara: Arkadaş Yayınevi.

Erten, P. (2019). Opinions of preservice information technologies teachers on virtual classroom and implementations. Batman University Journal of Life Sciences, 9(2), 236-252.

Fan, J., \& Zhi, L. (2020). Design and implementation of virtual immersive classroom in big data environment. The 15th International Conference on Computer Science \& Education (ICCSE 2020), pp.430432. August 18-20, 2020. Online

Ferri, F., Grifoni, P., \& Guzzo, T. (2020). Online learning and emergency remote teaching: Opportunities and challenges in emergency situations. Societies, 10(86), doi:10.3390/soc10040086.

Fidalgo, P., Thormann, J., Kulyk, O., \& Lencastre, J. A. (2020). Students' perceptions on distance education: A multinational study. International Journal of Educational Technology in Higher Education, 17(18), 1-18. https://doi.org/10.1186/s41239-020-00194-2.

Franklin, H., \& Harrington, I. (2019). A review into effective classroom management and strategies for student engagement: Teacher and student roles in today's classrooms. Journal of Education and Training Studies, 7(12), 1-12.

Gedera, D. S. P. (2014). Students' experiences of learning in a virtual classroom. International Journal of Education and Development using Information and Communication Technology (IJEDICT), 10(4), 93-101.

Kalelioğlu, F., Atan, A., \& Çetin, Ç. (2016). Sanal sınıf ortamında eğitmen ve öğrenen deneyimleri. Mersin Üniversitesi Ĕ̆itim Fakültesi Dergisi, 12(2), 555-568.

Karaman, S., Aydemir, M., Küçük, S., \& Yıldırım, G. (2013). Virtual classroom participants' views for effective synchronous education process. Turkish Online Journal of Distance Education-TOJDE, 14(1), 290-301.

Karasar, N. (2019). Bilimsel araştırma yöntemi. Ankara: Nobel Yayın Dağıtım.

Kaya, S. (2011). Sanal sınıf yönetiminde görev alacak öğretim elemanlarının eğitim gereksinimlerinin belirlenmesi. Doktora Tezi. Anadolu Üniversitesi, Eğitim Bilimleri Enstitüsü, Eskişehir.

Kaya, S. ve Ağaoğlu, E. (2013). Opinions of instructors related to the physical layout dimension of virtual classroom management. Literacy Information and Computer Education Journal (LICEJ), Special Issue, 2(1), 1342-1350.

Kırmacı, Ö. ve Acar, S. (2018). Kampüs öğrencilerinin eş zamanlı uzaktan eğitimde karşılaştıkları sorunlar. Ĕ̆itimde Kuram ve Uygulama, 14(3), 276-291.

Kingma, B., \& Keefe, S. (2006). An analysis of the virtual classroom: Does size matter? Do residencies make a difference? Should you hire that instructional designer? Journal of Education for Library and Information Science, Spring, 2006, 47(2), 127-143.

Li, S-C., Hsu, C-K., Chang, M., \& Heh, J. S. (1999). Competency-based training virtual classroom for vocational training on www. Tamkang Journal of Science and Engineering, 2(3), 119-131. 
Liu, Y. (2015). Design and application of a virtual classroom system in major courses in industrial arts. International Journal of Emerging Technologies in Learning (iJET), 10(5), 40-44.

Liu, Z. Y., Lomovtseva, N., \& Korobeynikova, E. (2020). Online learning platforms: Reconstructing modern higher education. International Journal of Emerging Technologies in Learning (iJET), 15(13), 421.

Lugrin, J-L., Latoschik, M.E., Habel, M., Roth, D., Seufert, C., \& Grafe, S. (2016). Breaking bad behaviors: A new tool for learning classroom management using virtual reality. Front. ICT, 3(26), https://www.frontiersin.org/articles/10.3389/fict.2016.00026/full Erişim tarihi: 24.01.2021

Martin, F., Parker, M.A., \& Ndoye, A. (2011). Measuring success in a synchronous virtual classroom. Student satisfaction and learning outcomes in E-Learning: An introduction to empirical research. Edt (Sean B. Eom., \& J.B. Arbaugh), USA: IGI Global.

Martin, J. (2019). Building relationships and increasing engagement in the virtual classroom: Practical tools for the online instructor. Journal of Educators Online, 16(1), 1-8.

Martin, F., \& Parker, M. A. (2014). Use of synchronous virtual classrooms: Why, Who, and How? MERLOT Journal of Online Learning and Teaching, 10(2), 192-210.

McGarr, O. (2020). The use of virtual simulations in teacher education to develop pre-service teachers' behaviour and classroom management skills: Implications for reflective practice. Journal of Education for Teaching, 46(1), 159-169.

Milliken, K. (2019). The implementation of online classroom management professional development for beginning teachers. Doctoral Thesis, Abilene Christian University, Texas, US. Digital Commons @ ACU, Electronic Theses and Dissertations. Paper 177.

Mills, J. (1996). Virtual classroom management and communicative writing pedagogy. Paper presented at the European Writing Conferences, pp:1-19. Barcelona, Spain, October 23-25.

Mishra, L., Gupta, T., \& Shreee, A. (2020). Online teaching-learning in higher education during lockdown period of COVID-19 pandemic. International Journal of Educational Research Open 1 (2020) 100012, https://doi.org/10.1016/j.ijedro.2020.100012

Pokhrel, S., \& Chhetri, R. (2021). A literature review on impact of COVID-19 Pandemic on teaching and learning. Higher Education for the Future 8(1) 133-141. http://dx.doi.org/10.1177/2347631120983481.

Rufai, M. M., Alebiosu, S.O., \& Adeakin, O. A. S. (2015). Conceptual model for virtual classroom management. International Journal of Computer Science, Engineering and Information Technology (IJCSEIT), 5(1), 27-32.

Stern, B. S. (2004). A comparison of online and face-to-face instruction in an undergraduate foundations of American education course. Contemporary Issues in Technology and Teacher Education, 4(2), $196-213$.

Şad, S.N. ve Yokuş, G. (2018). Eğitimin teknolojik temelleri. İçinde, Gülay Ekici (Edt.). Ĕ̆gitime Giriş (ss.339-376). Çanakkale: Paradigma Akademi.

Willmann, R., Zebedin, G., \& Miksche, D. (2020). Technical setup of an inverted virtual classroom. 2020 IEEE Global Engineering Education Conference (EDUCON), pp. 931-936. 27-30 April, 2020, Porto, Portugal.

Winther, J. G. (1999). Real issues in the virtual classroom. The French Review, 73(2), 252-264.

Yaşlıca, E. (2020). Sanal sınıf ortamında etkileşimli öğretim materyalinin başarıya ve tutuma etkisi. Anadolu Üniversitesi Sosyal Bilimler Dergisi, 20(1), 39-56.

Yılmazsoy, B., Özdinç, F. ve Kahraman, M. (2018). Sanal sınıf ortamında sınıf yönetimine yönelik öğrenci görüşleri: Afyon Kocatepe Üniversitesi Örneği. Trakya Ĕ̆itim Dergisi, 8(3), 513-525. 